Research, part of a Special Feature on Exploring Social-Ecological Resilience through the Lens of the Social Sciences: Contributions, Critical Reflections, and Constructive Debate

\title{
Studying the complexity of change: toward an analytical framework for understanding deliberate social-ecological transformations
}

\author{
Michele-Lee Moore $^{1}$, Ola Tjornbo ${ }^{2}$, Elin Enfors $^{3}$, Corrie Knapp $^{4}$, Jennifer Hodbod $^{5}$, Jacopo A. Baggio $^{6}$, Albert Norström $^{3}$, Per $^{2}$ \\ Olsson $^{3}$ and Duan Biggs ${ }^{7}$
}

\begin{abstract}
Faced with numerous seemingly intractable social and environmental challenges, many scholars and practitioners are increasingly interested in understanding how to actively engage and transform the existing systems holding such problems in place. Although a variety of analytical models have emerged in recent years, most emphasize either the social or ecological elements of such transformations rather than their coupled nature. To address this, first we have presented a definition of the core elements of a socialecological system (SES) that could potentially be altered in a transformation. Second, we drew on insights about transformation from three branches of literature focused on radical change, i.e., social movements, socio-technical transitions, and social innovation, and gave consideration to the similarities and differences with the current studies by resilience scholars. Drawing on these findings, we have proposed a framework that outlines the process and phases of transformative change in an SES. Future research will be able to utilize the framework as a tool for analyzing the alteration of social-ecological feedbacks, identifying critical barriers and leverage points and assessing the outcome of social-ecological transformations.
\end{abstract}

Key Words: resilience; social-ecological systems; social innovation; social movements; transformation; transition management

\section{INTRODUCTION}

From local to global scales, evidence is mounting that many human-environmental interactions have become "locked in" to unsustainable pathways (Scheffer et al. 2000, Folke et al. 2011). Consequently, interest has been growing about how to intentionally transform linked social-ecological systems (SESs) so that these systems are set on new trajectories to ensure that the well-being of both humans and a range of ecosystem services is sustained over time (Clark 2001, Leach et al. 2010, Westley et al. 2011).

However, at least two issues have emerged with this growth and in the ensuing scholarship focused on transformation in recent decades. First, academics and practitioners alike have begun to turn to the concepts of resilience and complexity from SES scholarship, seeking to understand how to exert agency to deliberately stimulate or support transformations toward more sustainable trajectories (Pelling 2011). Second, a variety of frameworks and case studies have emerged, which are portrayed as examples for understanding transformation (e.g., Geels 2002, Cinner et al. 2012). Across these discussions, a consensus has not emerged about what a transformation involves. Thus, questions remain about the types of changes in an SES that clearly represent a transformation.

We aim to achieve the following goals to advance discussions and research on transformations: (1) we will develop an analytical framework for defining and studying transformations across disciplinary perspectives; and, (2) in describing the multiple processes that comprise and contribute to transformations of SESs, we hope to build a more robust tool for actors who are participating in transformation processes to understand the points at which deliberate change and emergence, and agency and structure, may come into tension in different phases of transformation, and how they may be navigated.
To accomplish these goals, we first concentrate on one of the frameworks that has become widely cited in discussions of transformations of SESs, which was developed by Olsson et al. (2004). We contend that this existing framework is problematic in its existing form and thus requires refinement.

Olsson et al. (2004) describe transformation as a process with distinct phases. The phases are identified as follows: (1) preparing for change, (2) navigating the transition, and (3) building resilience of the new trajectory of development (Olsson et al. 2004, 2006, 2008). Although the original research and framework highlighted the important roles for shadow networks and leaders, subsequent research has illuminated the strategies used by institutional entrepreneurs and transformational leaders during transformation processes (Olsson et al. 2006, Sendzimir et al. 2007, Marshall et al. 2012, Westley et al. 2013). However, many of the strategies that are highlighted in this research, e.g., engaging stakeholders and framing narratives, are likely to be useful in more than one phase of a transformation process. However, we believe that the purpose for using each strategy, and their impacts, are likely to be different in each phase. Therefore, we argue that a layer can be added to the existing framework developed by Olsson et al. (2004), one that captures the multiple subprocesses that will occur in any one of the phases and that connects the broader phases with the strategies and agency of actors.

Additionally, the Olsson et al. (2004) framework, along with other existing transformation frameworks, provides limited insight into the role of power in transformation processes and tends to downplay the political nature of constructing alternative humanenvironment relationships or different trajectories. Significant scholarly effort has drawn attention to the need to consider issues of power asymmetry and social justice issues if any SES transformation is to be sustainable (e.g., Leach et al. 2010).

${ }^{1}$ Department of Geography, University of Victoria, ${ }^{2}$ Waterloo Institute of Social Innovation and Resilience, University of Waterloo, ${ }^{3}$ Stockholm Resilience Centre, Stockholm University, ${ }^{4}$ University of Alaska Fairbanks, ${ }^{5}$ Global Institute of Sustainability, Arizona State University, ${ }^{6}$ Center for the Study of Institutional Diversity, Arizona State University, ${ }^{7}$ The Centre for Biodiversity and Conservation Science, University of Queensland 
However, literature beyond SES scholarship has already studied these particular concerns. For instance, emerging research on social innovation has studied more closely the different processes that may be driven by actors and networks within transformation, along with the types of power wielded, and the varying metrics that can be useful for demonstrating transformative impacts (e.g., Antadze and Westley 2012, Moore and Tjornbo 2012). Similarly, research on transition management has established the critical role that active management of subprocesses, such as that of innovative "niches," may play in shaping the path of transformation (Rotmans et al. 2001, Caniëls and Romijn 2008). Additionally, social movement theorists, and particularly those studying environmental social movements, have brought light to bear on the contested nature of any social-ecological transformation (Lockie 2004, McCormick 2010). Therefore, we argue that the Olsson et al. (2004) framework for examining social-ecological transformations could be enhanced by the insights provided by three strands of social science literature: social innovation, transition management, and social movements. We focus on these three branches of the literature because of their explicit study of transformational change, as opposed to only incremental or adaptive change in SESs.

First, a thorough definition of the core elements of an SES that are altered in a transformation process will be established, which are defined based on existing SES research but are informed by other disciplinary literature as well. In Defining the potential for SES transformation, we combine perspectives from the three selected branches of literature focused on transformational change, i.e., social movements, transition management, and social innovation, to build a more complete consideration of social transformation processes that will lead to improved social and ecological outcomes. Our objective is not to provide a systematic review of the transformation literature, which is a study in its own right; rather, we integrate critical insights directly into the existing transformations framework developed by Olsson et al. (2004). Although scholars within all three branches of the literature draw on theoretical concepts from complex systems thinking at times, which overlaps with SES research, we believe that they also draw on distinct theoretical constructs that will enhance the overall understanding of transformation within SESs and, particularly, the multiple subprocesses that actors can expect to face when they are deliberately attempting to stimulate or support transformation. We hope that our definition and framework create greater clarity about what can be expected to change and how the processes underpinning that change will unfold in an SES transformation.

\section{DEFINING THE POTENTIAL FOR SES TRANSFORMATION}

\section{Defining the SES: "what" gets transformed}

Numerous SES scholars refer to the need for transformation (Carpenter and Folke 2006, Folke et al. 2010, Pelling 2011), but a consensus about the types of changes that would actually be observed if a transformation occurred remains elusive. We begin by defining the key parts of an SES and the feedbacks between them that could potentially change during a transformation.

We suggest that any analysis of a transformation needs to examine the following ecological elements: (1) natural capital, which includes the ecosystem processes, functions, and species configurations as described by Brand (2009); and (2) the ecosystem services that are generated by that natural capital. In using these two core elements, we build on previous research that has demonstrated that natural capital, ecosystem services, and their interactions can deliver human well-being and maintain ecosystem health (e.g., Biggs et al. 2012). Therefore, these elements provide a critical point of linkage between the social and ecological, and thus, if deliberate social transformations can be expected to alter a linked ecological system, it is these elements that are likely to be changed.

Building on the work of Westley and Antadze (2010), the key elements in social systems that can be expected to change during a transformation are the following: norms, values, and beliefs; rules and practices, such as laws, procedures, and customs; and the distribution and flow of power, authority, and resources. It must be noted that the elements of the social and ecological parts of a linked system identified by us are not homologous; that is, they are neither the same nor descend from a common origin as the notion of homology implies (Fitch 2000). Therefore, transforming any single component will be substantively different than transforming any other. However, each one serves to help maintain the structure, function, and identity of any system in the face of pressure and change, which is essential to the resilience of that linked system (Walker and Salt 2006). Therefore, we suggest (1) that these elements can be critical indicators to assess when determining whether a transformation of an SES has occurred, and (2) that the change in one of these core components has the potential to change the dominant feedbacks existing in an SES, consequently allowing a transformation to occur. Furthermore, feedbacks that reinforce these relationships are key to maintaining the overall configuration, or trajectory, of an SES (Enfors 2013). Thus, any transformation will also alter feedbacks in the system.

\section{Defining the SES: the role of scale}

Change in an SES typically takes the form of either an adaptation or transformation (Folke et al. 2010). Adaptation reflects the capacity of a system to adjust its responses to change in external drivers and internal processes (Smit and Wandel 2006, Tschakert and Dietrich 2010). For example, if overfishing reduced the abundance of one fish species, a natural predator of that species might change prey as an adaptation. However, this adaptive behavior in the ecological system will not necessarily alter any of the social or other ecological elements, or the feedback mechanisms between them, and, therefore, does not lead to a transformation. It is unlikely, for instance, that humans will stop fishing and transform their own dependence on fisheries as a food source because of this one predator's adaptation.

At a single scale, adaptation may lead to changes in the structures and activities of the system, but such change will remain confined to the scale where it was enacted. As long as an adaptation remains confined to a single scale and does not affect multiple socialecological elements, and as long as the dominant feedbacks between the ecological and social system do not change, we suggest that a transformation has not taken place.

Transformation, on the other hand, describes a form of change that is more significant than adaptation, one that recombines existing elements of a system in fundamentally novel ways. Transformations can be actively navigated or unintended (Chapin 
et al. 2010), but we focus on social-ecological transformations that are deliberate and actively navigated because of an understanding that "the current ecological, social or economic conditions become untenable or undesirable" (Nelson et al. 2007:297). Discussions are obviously raised regarding the normative nature of such judgments of desirability and concerns about who decides (O'Brien 2012), which we will discuss in $A$ framework for analyzing transformation in SES. Such transformations are also referred to as "purposive" or "directional" transformations (Berkhout 2002, Chapin et al. 2009). The alternative is a type of transformation associated with the effects of inadvertently crossing thresholds, an uncontrolled process that results from insufficient system resilience (Nelson et al. 2007). One would expect that inadvertent transformation is more likely to lead to undesirable system states with low productivity and less human well-being, whereas deliberate transformations are carried out with an intention to achieve a particular goal and, in doing so, create a fundamental shift that will enable desirable futures (Miller 2007). Transformations may start as changes at a single scale concerning a single element but lead to change at multiple scales and to multiple elements of the SES.

\section{A FRAMEWORK FOR ANALYZING TRANSFORMATION IN SESs}

Thus far, we have argued that an intentional SES transformation (1) can be triggered by a deliberate change in the key elements of either the social or ecological parts of the system across more than one scale, (2) that this change has impacts on the current dominant social-ecological feedbacks, and (3) that this leads to further changes in the structure of both the social and ecological parts of the system. According to the three strands of social literature reviewed, transformation is always somewhat unpredictable and nonlinear (Geels and Schot 2007, Goldstein et al. 2010); however, some clear patterns do still exist, and these form a common thread, or set of assumptions, about transformation that has inevitably informed our framework.

First, transformation of an SES toward a more sustainable trajectory is rare because the existing structures are typically mutually reinforcing and small perturbations can be accommodated through adaptation (Park et al. 2012). Powerful actors tend to be resistant to transformation pressures and work to keep the dominant system in place, as the social movement literature has previously demonstrated (Meyer and Staggenborg 1996, Staggenborg 2011). Therefore, when a transformation does occur, it typically is the result of a confluence of transformational pressures that have a cross-scale dimension (Smith et al. 2005). For instance, in Turkey, protest against increased local mining resulted in new regulations that altered the manner in which mining developed (Özen and Özen 2009). In this instance, powerful actors were able to change cross-scale feedbacks in such a way as to make transformation possible.

Second, when it does occur, transformation is not entirely random; it is shaped both by the existing elements and interactions between them, i.e., path dependency, and deliberate agency by actors within the system (Westley et al. 2013). A distinction must be made between the socio-technical transition and social movement literature, on the one hand, and social innovation scholarship, on the other. Transition management and social movement scholarship indicates that actors can select an end point and govern the transitions toward that predetermined state (Tarrow 1998, Kemp and Loorbach 2006), recognizing the constraints of existing structural power imbalances. However, social innovation scholars contend that the course of the transformation will emerge from the interplay of agency and structure rather than be determined by either alone (Westley et al. 2006, Nicholls and Murdock 2012). As such, actors do not control the course of a transformation; rather, they can only steer it somewhat toward their goals and influence the trajectory of the transformation process (Westley et al. 2013). Resilience and SES scholars have previously stated that although transformation end points will be uncertain, sometimes actors have a clear idea of where they do not want to end up, e.g., a degraded coral reef that delivers a lower level of ecosystem services (see Olsson et al. 2008, Folke et al. 2011).

Having articulated these two major assumptions that underpin our analytical framework, we now move to build on the Olsson et al. (2004) framework as a foundation for analyzing transformation processes. To accomplish this, we outline the critical subprocesses that scholars need to consider in any analysis of transformation (Table 1). It should be noted that although we present the phases and processes sequentially, the phases may occur simultaneously or in varying order in any transformation process.

\section{Triggers or "pretransformation"}

In general, scholars agree that although it is difficult to trace an exact starting point, transformations generally begin with a perturbation or crisis that serves as an opportunity (Table 1). Arguably, the perturbation could emerge internally or as an exogenous shock, and it could be social, e.g., civil unrest, election cycles, new resources, or new means of production/technology; or ecological, i.e., changes in climate or changes in soil composition or resource stocks. Ecosystems reaching a tipping point and moving toward a new regime that is entirely undesirable by anyone within the social system can be an important trigger (Scheffer et al. 2001, Biggs et al. 2009). In deliberate transformations, the more likely scenario is that actors will be trying to intentionally disrupt a dominant state that has become rigid but which locks the system into an unsustainable trajectory. The social movement literature demonstrates how marginalized groups can intentionally create such a disruption through acts of resistance and protest, and the varied sources of power that these actors may draw on even without an abundance of resources (Lin 2007, Taylor 2011). Although social movement theorists see the acts of resistance as the crux of the whole movement, they themselves are not "the transformation"; rather, they create conditions for transformability.

Such disruptions will weaken at least one or more of the social elements, but given the linked nature of an SES, they may also be associated with one or more ecological elements. To be clear, this weakening is not tantamount to a total collapse. Rather, social innovation research indicates that the disruption simply makes opportunities for intentional change more visible or transparent to agents within the system (Dorado 2005). For example, a new study that reports an alarming decline of ecosystem services, or a new protest campaign on a specific issue, can lead to a sudden reevaluation of existing legal frameworks and management 
Table 1. Framework for analyzing the multiple subprocesses in each phase of a social-ecological system transformation process.

Triggers or Pretransformation

Characterized by major social or ecological disruptions, which in turn, create windows of opportunity

Opportunity contexts change throughout the process of

transformation but typically become transparent enough at certain

points for agents to navigate to another phase

Preparing for change

Sensemaking - analysis of the structures that are most problematic for current trajectory

Envisioning - generating new innovations and visions for the future Gathering momentum - self-organization around new ideas, networks of support are often created and mobilized, experimentation in protected "niches"

Navigating the transition

Selecting - choosing which innovation or change process in which to invest social, intellectual, and financial capital

Learning - evaluating the results of earlier experiments and developing shared understandings or new forms of knowledge

Adoption - widespread uptake or replication of innovative change that was successful in experimental stage, tipping point

Scheffer et al. 2001, Olsson et al. 2006, Biggs et al. 2009, Moore et al. 2012

Institutionalizing the new trajectory

Routinization - managing dynamic stability to embed new trajectory and establish or strengthen new feedbacks

Strengthening cross-scale relationships - involves scaling up the change, which often involves a different type of innovation than was created originally in niche (needs to suit different contexts),

Stabilization - transformed system reaches new "attractor" but active resistance from powerful actors at different scales is likely, and actors need to deal with next, unanticipated perturbations
Crossley 2002, Olsson et al. 2004, Polletta 2004, Biggs et al. 2009, Gelcich et al. 2010

Dorado 2005, Westley et al. 2013

Kemp et al. 1998, Staggenborg 2011

Weisbord and Janoff 2000, Enfors et al. 2008

Olsson et al. 2004, 2006, 2008, Cumming et al. 2013, Moore and Westley 2011, Nyström et al. 2012, Seyfang and Haxeltine 2012, Smith and Raven 2012, Staggenborg 2011

Smith and Stirling 2010, Tjornbo and Westley 2012

Tarrow 1998, Geels 2002, Tilly 2004, Seyfang and Haxeltine 2012

Yin 1981, Larana et al. 1994, Chapin et al. 2010, Folke et al. 2010, Nyström et al. 2012

Westley and Antadze 2010, Moore et al. 2012 practices. In these instances, new opportunities emerge for actors to influence change (see, e.g., Riddell et al. 2012).

\section{Preparing for change: sense making, envisioning, and gathering momentum}

In the current SES literature, Olsson et al. (2004) propose that a preparation phase is needed to respond to any sort of "trigger." However, it remains unclear "who" ought to prepare the system for change or the rate at which this should be undertaken. Social movement literature predominantly focuses on the "collective," although scholars recognize the significance of leaders within the collective (Crossley 2002). However, social innovation and transition management research contends that institutional and policy entrepreneurs will likely be the most effective at challenging the current trajectory and finding key leverage points to accomplish this challenge (Schot et al. 1994, Huitema et al. 2011, Moore and Westley 2011). The challenge is that depending on the power and interests of who controls or leads this stage, they may fail to consider how the transformation might influence the suite of social and ecological processes (Foucault and Hoy 1986). We propose that any analysis of transformation needs to consider both types of actors, i.e., collectives and individuals, and how they may be shaping this process.
Regardless of who leads, we argue that three subprocesses are critical to this phase, including sense making, envisioning, and gathering momentum. Building on Olsson et al. (2004), social innovation and social movement research shows that for actors to prepare the system for transformation, the first step involves making sense of the current situation, by analyzing what elements of the SES and the scales of those elements make the system's current trajectory most problematic or vulnerable. Sense making is a process by which individuals "construct meaningful explanations for situations and their experiences within those situations" (Gioia 1986:61). Such a process is necessary when the need for change is evident but the "how" or "what" to change is not (Moore et al. 2012). However, it can also be viewed as a deliberate process whereby actors are able to assert their interpretation of a problem and mobilize others to self-organize around a new idea or practice that addresses the issue (Kemp et al. 1998, Weick and Sutcliffe 2007). In the social movement literature, this is described as building "collective action frames," which create a common story and purpose to motivate action (Staggenborg 2011).

Sense making is often followed by attempts to create an understanding that a different order of things is possible, or 
envisioning alternative pathways. In an SES, the process may involve imagining how a fundamental change in humanenvironment relations could manifest, in terms of alternative management practices, organizational forms, or cognitive relations to nature. Scenario planning or other participatory planning processes may be useful tools for the process of envisioning because they force people to think explicitly about alternative situations and consider key uncertainties (e.g., Enfors et al. 2008). Although numerous case studies demonstrate the value of such envisioning and participatory planning processes, there is often an implicit assumption that once different scenarios are established and agreed on, the preferred scenario will automatically be implemented, even though this is rarely the case. Thus, our analytical framework highlights that envisioning is simply one subprocess in one phase of a much broader development.

Having undertaken sense making and the development of a new vision, the next step is to gather momentum to move the system in that direction, typically achieved by convening a coalition of supporters. Social movement theorists describe the range of techniques to mobilize support (Tarrow 1998, Tilly 2004). One such mechanism, which has been recognized by SES, social movement, and social innovation scholars alike (Moore and Westley 2011, Staggenborg 2011), involves developing networks that help to build a shared identity for those desiring transformation. Building support networks can be especially important in highly complex and uncertain environments when change is deemed necessary but impossible for any one actor to achieve. However, it should be noted that different network structures will be important in different phases of the transformation process, and therefore, individuals will need to utilize different skill sets to mobilize the resources from within those network structures at various points in the transformation process (Moore and Westley 2011).

In addition to support, a clear understanding of which imagined scenario holds the most promise is needed. The act of making these strategic decisions to select a specific trajectory or scenario is often neglected by SES scholarship (Marshall et al. 2012). To build this understanding and to make an informed choice, experimentation with alternatives that allows people to learn about social-ecological links and feedbacks is crucial (Geels 2002, Nyström et al. 2012). In turn, this demands that arenas for experimentation and innovation testing exist. In the literature on social transitions, the concept of transformative niches is used to describe spaces where new radical innovations are tested and developed (Seyfang and Haxeltine 2012, Smith and Raven 2012). Although transition management theorists have predominantly focused on technical innovations, social innovation research reminds us that transformative innovations will be social, including processes, practices, policies, or programs, and not mere technical products. Macrolevel institutions can create the opportunities for niches to develop, or the niches may selforganize out of grass-roots efforts and, later, transform the institutions. These "protected" spaces allow for new types of social-ecological dynamics to emerge (Cumming et al. 2013). Eventually, experiments that are successful within niches can provide innovations that may be scaled up and out in subsequent phases.

\section{Navigating the transition: selecting, learning, and adopting}

When newly tested innovations have the potential to alter major social and ecological structures across multiple scales, transition management theorists argue that they may begin to be accepted, i.e., pull effect, or intensively advocated, i.e., push effect, as the protected niche develops (Smith and Raven 2012). Transition management scholars also claim that an innovation can "take off" at this stage, enabled by an opportunity that makes the system more open for change (Geels 2005). Therefore, actors attempting to deliberately stimulate or steer a transformation need to be aware that three important processes characterize the navigating phase: selecting, learning, and adopting.

Typically, multiple, competing pathways are possible at this point, depending on how many possible scenarios were generated during the previous envisioning activities. Thus, navigating toward the transition will require that the networks and social movements that have been generating momentum and support for change will need to go through a process of selecting the ideas or practices that were previously tested in a niche and that will come to dominate posttransformation (Smith and Stirling 2010). Social innovation research cautions that this phase is often skipped, and consequently, resources, including financial, social, and intellectual capital, are spread too thin (Moore et al. 2012, Tjornbo and Westley 2012).

Transition management and social innovation literature emphasizes the importance of learning in this phase because learning helps to inform the selection process. Although the social movement literature also recognizes learning, describing it as occurring by developing and sharing collective action frames (Tarrow 1998, Tilly 2004), social movement theorists also recognize that those with structural power will tend to more easily dominate the selection process. Thus, issues of equity, vulnerability, and democratic process are acute for the "selection" activities (Tilly 2004). Consequently, actors seeking to stimulate or support transformation could benefit from an evaluation process that directly examines these issues, as well as helps to determine if changes to core elements of the social and ecological system within any scale are being altered in a way that supports a more resilient trajectory for the system.

Adoption is the last key process of the navigation phase. In the social innovation, social transition, and social movement literature, adoption is understood to involve the widespread uptake of a novel idea into the mainstream. Often, the adoption period is referred to as "diffusion" or "scaling out" by those interested in general innovation (Moore et al. 2012). However, all three theoretical strands, as well as the original Olsson et al. (2004) framework, focus on the role of social outcomes in this process, while largely neglecting the role of ecological outcomes. We argue that actors will need to evaluate both ecological and social outcomes at different scales and the related feedbacks before adopting a new idea or practice. Otherwise, transformations may occur that do not improve the capacity to learn from, respond to, and manage dynamic systems.

Institutionalizing the new trajectory: routinization, strengthening cross-scale relationships, and stabilization

Although Olsson et al. (2006) refer to this phase as "building resilience," we have reframed this phase to emphasize the need to institutionalize any new trajectory. We propose that as adoption 
occurs, new dominant social-ecological feedbacks become established and strengthened. However, these may result from emergent, self-organizing properties of the system and may not entirely be determined by the strategic agency of an actor or collective social movement. Therefore, the challenge within this phase is building the resilience of the new trajectory by strengthening positive feedbacks, while simultaneously maintaining adaptive and transformative capacity to respond to unanticipated perturbations in the future (Chapin et al. 2010, Folke et al. 2010). It is the combination of building stability and remaining able to change that is referred to as "dynamic stability" (Folke et al. 2011). Key processes in this phase are routinization, strengthening cross-scale relationships, and stabilizing.

Routinization within the social elements of an SES marks an important transition from the period in which new practices for a new trajectory are adopted to one in which these practices become standard (Bartunek et al. 2007). Previous scholarship indicates that the process of routinization involves the following: (1) the dedication of funds to the new process or program and (2) the classification of personnel involved in implementing and maintaining this now standard practice (Yin 1981). Furthermore, routinization will typically require corresponding changes to laws and organizational structures (Moore et al. 2012). The importance of such changes is that they are likely to outlast the informal networks and involvement of entrepreneurial agents that have influenced the transformation in the previous two phases (Moore et al. 2012). In fact, this particular phase will likely involve leadership from different agents than the charismatic leaders who may have been involved in the earlier phases because routinization requires very different skill sets than the generation or envisioning of a new trajectory (Westley et al. 2013). We interpret that much of the social movement literature treats this as a period when "success" has been achieved or a social movement is largely "done," although new social movement theorists do argue that existing networks may just become latent and "hidden" until their activation is required once more (Larana et al. 1994). Our contention is that a transformation that will be durable in impact and affect broader scales or other structures will still require this entire phase.

For the ecological elements, routinization can be understood to involve a period in which new dominant feedbacks stabilize ecosystem services and natural capital into the new trajectory (Nyström et al. 2012). Although metaphorical concepts, such as the notion of an "attractor" in a stability landscape (Walker and Salt 2006, Scheffer 2010), help to identify the dynamics involved in ecological structures significantly changing and then restabilizing, there is still a paucity of understanding regarding the full mechanisms at work. Thus, actors involved in deliberately steering a transformation will need to be attentive to attractors and to shifting feedback mechanisms.

Although Olsson et al. (2004) acknowledge the importance of cross-scale interactions during the transformation process, we argue that it is more precise to consider this phase as marked by efforts to scale up new approaches or practices to create change across multiple scales, based on social innovation research. Recalling that the previous phase involves the adoption of a new policy or practice that will contribute to the transformation of the SES, adoption often focuses on scaling out, defined as a replication of that practice or policy in several different locations
(Moore et al. 2012). Scaling up often requires a different type of policy or initiative than was originally created, or it may involve different natural capital or different ecosystem services at a scale above or below the scale at which the transformation process began (Westley and Antadze 2010).

In strengthening the cross-scale interactions and undertaking processes for routinization, stabilization of the new trajectory may occur. However, stabilization involves two main concerns. First, throughout any transformation process, there is likely to be active resistance by actors with power or by dominant species in a particular ecosystem (Avelino and Rotmans 2009, Moore and Tjornbo 2012). As social movement theorists have demonstrated repeatedly, these actors can weaken the efforts for change, and in particular, we contend that they can serve as a barrier to changing feedback loops, or that they may change them in unintended ways (Özen and Özen 2009). It is important that anyone exerting agency in this phase continues to push for small "wins" in achieving a more sustainable trajectory and resists attempts by others to keep redefining or reverting from the potential transformation. Second, given the uncertainty that exists around social-ecological interconnections and feedback mechanisms, unintended consequences may appear in this phase (Westley et al. 2006). Responding to emergent concerns while preparing to address future windows of opportunity for change will ensure that the transformation process reaches stability, but that it is not treated as a final end point. For with the dynamics of any transformation, change and stability will be an ongoing relationship.

\section{CONCLUSIONS}

Numerous reasons exist for why individuals or collectives may be interested in deliberately stimulating or supporting transformation of SESs. For instance, in international development, transformation may be desired when the existing social-ecological conditions are holding the system in a poverty trap. In conservation management, transformation may be important for regions where humans are degrading the capacity of the system to self-organize, maintain diversity, and provide critical ecosystem functions. Given the heightened attention to the idea that humans need to actively transform our current, unsustainable systems, we have attempted to provide a clear definition of what a transformation entails and a framework for conceptualizing the multiple subprocesses that comprise the various phases of a transformation in linked SESs.

The result is that we have defined the core social and ecological elements that may potentially be altered in any transformation process, recognizing that feedback mechanisms between those elements will also change. Ultimately, we propose that there is a minimum specification as to what constitutes a transformation of an SES; that is, at least one core element in each of the social and ecological parts of the system across multiple scales must be altered for it to constitute a potential transformation. In turn, this will change the dominant feedbacks, and a new feedback will emerge. We recognize that this maintains a dualistic perspective of the social and the ecological parts of a system, rather than adopting an integrated approach. However, we contend that greater analytical specificity can be developed by continuing to treat the elements of a system as linked, but not homologous.

We have also outlined how the enhancement of the existing Olsson et al. (2004) framework can give more careful consideration to both power and the subprocesses that will exist in any 
transformation, which is well supported by existing research on social innovation, transition management, and social movements. The social movement literature repeatedly highlights that any transformative change will only be sustainable if it creates more just circumstances. However, opportunities to reinforce the power of dominant actors while marginalizing others are numerous and can particularly shape the trajectory if not countered during the preparatory phase. However, all three strands of literature remind us that groups marginalized by the current system often stimulate transformations and use alternative sources of power throughout the process. Finally, though, social innovation literature is explicit that the idea of neutralizing or depoliticizing transformation processes is neither possible, nor even desirable, given that any durable transformation will require altering the dominant structures of power and embedding the newly reconfigured socialecological elements and feedbacks within our institutions so that the new trajectory itself gains power.

The potential exists for scholars across disciplines to utilize the framework as a tool for analyzing the alteration of socialecological feedbacks, identifying critical barriers and leverage points within the processes, and assessing the outcome of socialecological transformations. Additionally, such testing will help to further refine the framework. However, we believe that this framework provides an important contribution to bridge the social and ecological understandings of transformation so that a more integrated approach can be applied in the future.

Responses to this article can be read online at: http://www.ecologyandsociety.org/issues/responses. $\mathrm{php} / 6966$

\section{Acknowledgments:}

The authors would like to acknowledge the support of the Resilience Alliance Young Scholars (RAYS) network in developing the Transformations project. Support for J. A. Baggio's contribution was provided by the Haynes Foundation, Center for the Study of Institutional Diversity and NSF Grant GEO-1115054.

\section{LITERATURE CITED}

Antadze, N., and F. R. Westley. 2012. Impact metrics for social innovation: barriers or bridges to radical change? Journal of Social Entrepreneurship 3(2):133-150. http://dx.doi. org/10.1080/19420676.2012.726005

Avelino, F., and J. Rotmans. 2009. Power in transition: an interdisciplinary framework to study power in relation to structural change. European Journal of Social Theory 12 (4):543-569. http://dx.doi.org/10.1177/1368431009349830

Bartunek, J. M., J. Trullen, S. Immediato, and F. Schneider. 2007. Front and backstages of the diminished routinization of innovations: what innovation research makes public and organizational research finds behind the scenes. Strategic Entrepreneurship Journal 1(3-4):295-314. http://dx.doi.org/10.1002/ $\underline{\text { sej. } 21}$
Berkhout, F. 2002. Technological regimes, path dependency and the environment. Global Environmental Change 12(1):1-4. http:// dx.doi.org/10.1016/S0959-3780(01)00025-5

Biggs, R., S. R. Carpenter, and W. A. Brock. 2009. Turning back from the brink: detecting an impending regime shift in time to avert it. Proceedings of the National Academy of Sciences of the United States of America 106(3):826-831. http://dx.doi. org/10.1073/pnas.0811729106

Biggs, R., M. Schlüter, D. Biggs, E. L. Bohensky, S. BurnSilver, G. Cundill, V. Dakos, T. M. Daw, L. S. Evans, K. Kotschy, A. M. Leitch, C. Meek, A. Quinlan, C. Raudsepp-Hearne, M. D. Robards, M. L. Schoon, L. Schultz, and P. C. West. 2012. Towards principles for enhancing the resilience of ecosystem services. Annual Review of Environment and Resources 37:421-448. http:// dx.doi.org/10.1146/annurev-environ-051211-123836

Brand, F. 2009. Critical natural capital revisited: ecological resilience and sustainable development. Environmental Economics 68(3):605-612. http://dx.doi.org/10.1016/j.ecolecon.2008.09.013

Caniëls, M. C. J., and H. A. Romijn. 2008. Strategic niche management: towards a policy tool for sustainable development. Technology Analysis \& Strategic Management 20(2):245-266. http://dx.doi.org/10.1080/09537320701711264

Carpenter, S. R., and C. Folke. 2006. Ecology for transformation. Trends in Ecology \& Evolution 21(6):309-315. http://dx.doi. org/10.1016/j.tree.2006.02.007

Chapin, F. S., III, S. R. Carpenter, G. P. Kofinas, C. Folke, N. Abel, W. C. Clark, P. Olsson, D. M. Stafford Smith, B. Walker, O. R. Young, F. Berkes, R. Biggs, J. M. Grove, R. L. Naylor, E. Pinkerton, W. Steffen, and F. J. Swanson. 2010. Ecosystem stewardship: sustainability strategies for a rapidly changing planet. Ecology and Evolution 25(4):241-249. http://dx.doi. org/10.1016/j.tree.2009.10.008

Chapin, F. S., III, G. P. Kofinas, and C. Folke. 2009. Principles of ecosystem stewardship: resilience-based natural resource management in a changing world. Springer, Berlin, Germany.

Cinner, J. E., T. M. Daw, T. R. McClanahan, N. Muthiga, C. Abunge, S. Hamed, B. Mwaka, A. Rabearisoa, A. Wamukota, E. Fisher, and N. Jiddawi. 2012. Transitions toward co-management: the process of marine resource management devolution in three east African countries. Global Environmental Change 22 (3):651-658. http://dx.doi.org/10.1016/j.gloenvcha.2012.03.002

Clark, W. C. 2001. A transition toward sustainability. Ecology Law Quarterly 27(4):1021-1076.

Crossley, N. 2002. Making sense of social movements. Open University Press, Buckingham, UK.

Cumming, G. S., P. Olsson, Chapin, F. S., III, and C. S. Holling. 2013. Resilience, experimentation, and scale mismatches in socialecological landscapes. Landscape Ecology 28(6):1139-1150. http://dx.doi.org/10.1007/s10980-012-9725-4

Dorado, S. 2005. Institutional entrepreneurship, partaking, and convening. Organization Studies 26(3):385-414 http://dx.doi. org/10.1177/0170840605050873 
Enfors, E. 2013. Social-ecological traps and transformations in dryland agro-ecosystems: using water system innovations to change the trajectory of development. Global Environmental Change 23(1):51-60. http://dx.doi.org/10.1016/j.gloenvcha.2012.10.007

Enfors, E. I., L. J. Gordon, G. D. Peterson, and D. Bossio. 2008. Making investments in dryland development work: participatory scenario planning in the Makanya catchment, Tanzania. Ecology and Society 13(2): 42. [online] URL: http://www.ecologyandsociety. org/vol13/iss2/art42/

Fitch, W. M. 2000. Homology: a personal view on some of the problems. Trends in Genetics 16(5):227-231. http://dx.doi. org/10.1016/S0168-9525(00)02005-9

Folke, C., S. R. Carpenter, B. Walker, M. Scheffer, T. Chapin, and J. Rockström. 2010. Resilience thinking: integrating resilience, adaptability and transformability. Ecology and Society 15(4): 20. [online] URL: http://www.ecologyandsociety.org/vol15/iss4/ $\underline{\operatorname{art} 20 /}$

Folke, C., Å. Jansson, J. Rockström, P. Olsson, S. R. Carpenter, F. S. Chapin III, A.-S. Crépin, G. Daily, K. Danell, J. Ebbesson, T. Elmqvist, V. Galaz, F. Moberg, M. Nilsson, H. Österblom, E. Ostrom, Å. Persson, G. Peterson, S. Polasky, W. Steffen, B. Walker, and F. Westley. 2011. Reconnecting to the biosphere. AMBIO 40 (7):719-738. http://dx.doi.org/10.1007/s13280-011-0184-y

Foucault, M., and D. C. Hoy. 1986. Foucault: a critical reader. Blackwell, Oxford, UK.

Geels, F. W. 2002. Technological transitions as evolutionary reconfiguration processes: a multi-level perspective and a casestudy. Research Policy 31(8-9):1257-1274. http://dx.doi. org/10.1016/S0048-7333(02)00062-8

Geels, F. W. 2005. Processes and patterns in transitions and system innovations: refining the co-evolutionary multi-level perspective. Technological Forecasting and Social Change 72(6):681-696. http://dx.doi.org/10.1016/j.techfore.2004.08.014

Geels, F. W., and J. Schot. 2007. Typology of sociotechnical transition pathways. Research Policy 36(3):399-417. http://dx.doi. org/10.1016/j.respol.2007.01.003

Gelcich, S., T. P. Hughes, P. Olsson, C. Folke, O. Defeo, M. Fernández, S. Foale, L. H. Gunderson, C. Rodríguez-Sickert, M. Scheffer, R. S. Steneck, and J. C. Castilla. 2010. Navigating transformations in governance of Chilean marine coastal resources. Proceedings of the National Academy of Sciences of the United States of America 107(39):16794-16799. http://dx.doi. org/10.1073/pnas.1012021107

Gioia, D. A. 1986. Symbols, scripts, and sensemaking: creating meaning in the organizational experience. Pages 49-74 in H. P. Sims and D. A. Gioia, editors. The thinking organization. JosseyBass, San Francisco, California, USA.

Goldstein, J., J. K. Hazy, and J. Silberstang. 2010. A complexity science model of social innovation in social enterprise. Journal of Social Entrepreneurship 1(1):101-125. http://dx.doi. org/10.1080/19420671003629763

Huitema, D., L. Lebel, and S. Meijerink. 2011. The strategies of policy entrepreneurs in water transitions around the world. Water Policy 13(5):717-733. http://dx.doi.org/10.2166/wp.2011.107
Kemp, R., and D. Loorbach. 2006. Transition management: a reflexive governance approach. Pages 103-130 in J.-P. Voß, D. Bauknecht, and R. Kemp, editors. Reflexive governance for sustainable development. Edward Elgar, Cheltenham, UK. http:// dx.doi.org/10.4337/9781847200266.00015

Kemp, R., J. Schot, and R. Hoogma. 1998. Regime shifts to sustainability through processes of niche formation: the approach of strategic niche management. Technology Analysis \& Strategic Management 10(2):175-198. http://dx.doi.org/10.1080/09537329$\underline{808524310}$

Larana, E., J. Hank, and G. Joseph. 1994. New social movements: from ideology to identity. Temple University Press, Philadelphia, Pennsylvania, USA.

Leach, M., I. Scoones, and A. Stirling. 2010. Dynamic sustainabilities: technology, environment and social justice. Earthscan, London, UK.

Lin, T. C. 2007. Environmental NGOs and the anti-dam movements in China: a social movement with Chinese characteristics. Issues \& Studies 43(1):149-184.

Lockie, S. 2004. Collective agency, non-human causality and environmental social movements: a case study of the Australian 'landcare movement.' Journal of Sociology 40(1):41-57. http://dx. doi.org/10.1177/1440783304040452

Marshall, N. A., S. E. Park, W. N. Adger, K. Brown, and S. M. Howden. 2012. Transformational capacity and the influence of place and identity. Environmental Research Letters 7(3):034022. http://dx.doi.org/10.1088/1748-9326/7/3/034022

McCormick, S. 2010. Damming the Amazon: local movements and transnational struggles over water. Society \& Natural Resources 24(1):34-48. http://dx.doi.org/10.1080/08941920903278129

Meyer, D. S., and S. Staggenborg. 1996. Movements, countermovements, and the structure of political opportunity. American Journal of Sociology 101(6):1628-1660. http://dx.doi. org/10.1086/230869

Miller, R. 2007. Futures literacy: a hybrid strategic scenario method. Futures 39(4):341-362. http://dx.doi.org/10.1016/j. futures.2006.12.001

Moore, M.-L., and O. Tjornbo. 2012. From coastal timber supply area to Great Bear Rainforest: exploring power in a socialecological governance innovation. Ecology and Society 17(4): 26. http://dx.doi.org/10.5751/ES-05194-170426

Moore, M., and F. Westley. 2011. Surmountable chasms: networks and social innovation for resilient systems. Ecology and Society 16(1): 5. [online] URL: http://www.ecologyandsociety. org/vol16/iss1/art5

Moore, M.-L., F. R. Westley, O. Tjornbo, and C. Holroyd. 2012. The loop, the lens, and the lesson: using resilience theory to examine public policy and social innovation. Pages 89-113 in A. Nicholls and A. Murdoch, editors. Social innovation: blurring boundaries to reconfigure markets. Palgrave Macmillan, Basingstoke, UK.

Nelson, D. R., W. N. Adger, and K. Brown. 2007. Adaptation to environmental change: contributions of a resilience framework. 
Annual Review of Environment and Resources 32(1):395-419. http://dx.doi.org/10.1146/annurev.energy.32.051807.090348

Nicholls, A., and A. Murdock, editors. 2012. Social innovation: blurring boundaries to reconfigure markets. Palgrave Macmillan, Basingstoke, UK. http://dx.doi.org/10.1057/9780230367098

Nyström, M., A. V. Norström, T. Blenckner, M. de la TorreCastro, J. S. Eklöf, C. Folke, H. Österblom, R. S. Steneck, M. Thyresson, and M. Troell. 2012. Confronting feedbacks of degraded marine ecosystems. Ecosystems 15(5):695-710. http:// dx.doi.org/10.1007/s10021-012-9530-6

O'Brien, K. 2012. Global environmental change II: from adaptation to deliberate transformation. Progress in Human Geography 36(5):667-676. http://dx.doi.org/10.1177/0309132511425767

Olsson, P., C. Folke, and T. Hahn. 2004. Social-ecological transformation for ecosystem management: the development of adaptive co-management of a wetland landscape in southern Sweden. Ecology and Society 9(4): 2. [online] URL: http://www. ecologyandsociety.org/vo19/iss4/art2/

Olsson, P., C. Folke, and T. P. Hughes. 2008. Navigating the transition to ecosystem-based management of the Great Barrier Reef, Australia. Proceedings of the National Academy of Sciences of the United States of America 105(28):9489-9494. http://dx.doi. org/10.1073/pnas.0706905105

Olsson, P., L. H. Gunderson, S. R. Carpenter, P. Ryan, L. Lebel, C. Folke, and C. S. Holling. 2006. Shooting the rapids: navigating transitions to adaptive governance of social-ecological systems. Ecology and Society 11(1): 18. [online] URL: http://www. ecologyandsociety.org/vol11/iss1/art18

Özen, Ş., and H. Özen. 2009. Peasants against MNCs and the state: the role of the Bergama struggle in the institutional construction of the gold-mining field in Turkey. Organization 16 (4):547-573. http://dx.doi.org/10.1177/1350508409104508

Park, S. E., N. A. Marshall, E. Jakku, A. M. Dowd, S. M. Howden, E. Mendham, and A. Fleming. 2012. Informing adaptation responses to climate change through theories of transformation. Global Environmental Change 22(1):115-126. http://dx.doi. org/10.1016/j.gloenvcha.2011.10.003

Pelling, M. 2011. Adaptation to climate change: from resilience to transformation. Routledge, New York, New York, USA.

Polletta, F. 2004. Culture in and outside institutions. Pages 161-183 in D. J. Myers and D. M. Cress, editors. Authority in contention. Research in Social Movements, Conflicts, and Change Series, Volume 25. Emerald Group, Bingley, UK. http://dx.doi. org/10.1016/S0163-786X(04)25007-8

Riddell, D., O. Tjörnbo, and F. Westley. 2012. Agency and innovation in a phase of turbulent change: conservation in the Great Bear Rainforest. Pages 155-180 in K. Golden-Biddle and J. E. Dutton, editors. Using a positive lens to explore social change and organizations: building a theoretical and research foundation. Routledge Academic, Oxford, UK.

Rotmans, J., R. Kemp, and M. Van Asselt. 2001. More evolution than revolution: transition management in public policy. Foresight 3(1):15-31. http://dx.doi.org/10.1108/14636680110803003
Scheffer, M. 2010. Complex systems: foreseeing tipping points. Nature 467(7314):411-412. http://dx.doi.org/10.1038/467411a

Scheffer, M., W. Brock, and F. R. Westley. 2000. Socioeconomic mechanisms preventing optimum use of ecosystem services: an interdisciplinary theoretical analysis. Ecosystems 3(5):451-471. http://dx.doi.org/10.1007/s100210000040

Scheffer, M., S. Carpenter, J. A. Foley, C. Folke, and B. Walker. 2001. Catastrophic shifts in ecosystems. Nature 413:591-596. http://dx.doi.org/10.1038/35098000

Schot, J., R. Hoogma, and B. Elzen. 1994. Strategies for shifting technological systems: the case of the automobile system. Futures 26(10):1060-1076. http://dx.doi.org/10.1016/0016-3287(94)90073-6

Sendzimir, J., P. Magnuszewski, Z. Flachner, P. Balogh, G. Molnar, A. Sarvari, and Z. Nagy. 2007. Assessing the resilience of a river management regime: informal learning in a shadow network in the Tisza River Basin. Ecology and Society 13(1): 11. [online] URL: http://www.ecologyandsociety.org/vol13/iss1/ $\underline{\operatorname{art} 11 /}$

Seyfang, G., and A. Haxeltine. 2012. Growing grassroots innovations: exploring the role of community-based initiatives in governing sustainable energy transitions. Environment and Planning C: Government and Policy 30(3):381-400. http://dx.doi. org/10.1068/c10222

Smit, B., and J. Wandel. 2006. Adaptation, adaptive capacity and vulnerability. Global Environmental Change 16(3):282-292. http:// dx.doi.org/10.1016/j.gloenvcha.2006.03.008

Smith, A., and R. Raven. 2012. What is protective space? Reconsidering niches in transitions to sustainability. Research Policy 41(6):1025-1036. http://dx.doi.org/10.1016/j.respol.2011.12.012

Smith, A., and A. Stirling. 2010. The politics of social-ecological resilience and sustainable socio-technical transitions. Ecology and Society 15(1): 11. [online] URL: http://www.ecologyandsociety. org/vol15/iss1/art11/

Smith, A., A. Stirling, and F. Berkhout. 2005. The governance of sustainable socio-technical transitions. Research Policy 34 (10):1491-1510. http://dx.doi.org/10.1016/j.respol.2005.07.005

Staggenborg, S. 2011. Socialmovements. Oxford University Press, New York, New York, USA.

Tarrow, S. 1998. Power in movement: social movements and contentious politics. Cambridge University Press, Cambridge, UK. http://dx.doi.org/10.1017/CBO9780511813245

Taylor, L. 2011. Environmentalism and social protest: the contemporary anti-mining mobilization in the province of San Marcos and the Condebamba Valley, Peru. Journal of Agrarian Change 11(3):420-439. http://dx.doi.org/10.1111/j.1471-0366.2011.00313. $\underline{\mathrm{X}}$

Tilly, C. 2004. Social movements, 1768-2004. Paradigm, Boulder, CO. http://dx.doi.org/10.7208/chicago/9780226803531.003.0008

Tjornbo, O., and F. R. Westley. 2012. Game changers: the big green challenge and the role of challenge grants in social innovation. Journal of Social Entrepreneurship 3(2):166-183. http://dx.doi.org/10.1080/19420676.2012.726007 
Tschakert, P., and K. A. Dietrich. 2010. Anticipatory learning for climate change adaptation and resilience. Ecology and Society 15 (2): 11. [online] URL: http://www.ecologyandsociety.org/vol15/ iss $2 / \operatorname{art} 11 /$

Walker, B. H., and D. A. Salt. 2006. Resilience thinking: sustaining ecosystems and people in a changing world. Island, Washington, D.C., USA.

Weick, K. E., and K. M. Sutcliffe. 2007. Managing the unexpected: resilience performance in an age of uncertainty. John Wiley and Sons, San Francisco, California, USA.

Westley, F. R., and N. Antadze. 2010. Making a difference: strategies for scaling social innovation for greater impact. Public Sector Innovation Journal 15(2): 2. [online] URL: http://www. innovation.cc/scholarly-style/westley2antadze2make difference final. pdf

Westley, F., P. Olsson, C. Folke, T. Homer-Dixon, H. Vredenburg, D. Loorbach, J. Thompson, M. Nilsson, E. Lambin, J. Sendzimir, B. Banerjee, V. Galaz, and S. van der Leeuw. 2011. Tipping towards sustainability: emerging pathways of transformation. AMBIO 40(7):762-780. http://dx.doi.org/10.1007/s13280-011-0186-9

Westley, F. R., O. Tjornbo, L. Schultz, P. Olsson, C. Folke, B. Crona, and Ö. Bodin. 2013. A theory of transformative agency in linked social-ecological systems. Ecology and Society 18(3): 27. http://dx.doi.org/10.5751/ES-05072-180327

Westley, F. R., B. Zimmerman, and M. Q. Patton. 2006. Getting to maybe: how the world is changed. Vintage Canada, Toronto, Ontario, Canada.

Yin, R. K. 1981. Life histories of innovations: how new practices become routinized. Public Administration Review 41(1):21-28. http://dx.doi.org/10.2307/975720 